\title{
POVERTY BUDGETS: HOW MUCH IS ENOUGH?
}

\author{
Alan Haber, The University of Michigan
}

The current "poverty line," as recently developed by the Social Security Administration, is defined as $\$ 3,130$ annual income for a nonfarm family of four and $\$ 1,850$ for an elderly couple. 1 Those below that line are poor; those above it are somehow able to carry on without being the special object of social policy.

The new poverty definition has been greeted with almost universal acclaim by students of poverty, since it overcomes many of the failings of earlier definitions. It is a variable measure, adjusted for family size, age, geographical region and urban or farm residence. Furthermore, it is based on an explicit methodology, rather than on an arbitrary or impressionistic standard, such as the $\$ 3,000$ line for a family of four widely used by the Council of Economic Advisors and many independent researchers.

Unfortunately, both as a measure of "poverty" and as a guide to social policy, this minimum nonpoverty income figure has severe weaknesses. Its data do not conform to the conditions imposed by its explicit assumptions, and hence, is deceptive as a measure of well-being. Its implicit assumptions about the life conditions of the poor are unrealistic. It uses data which appear to be inaccurate and thereby greatly understate the poverty income levels that its methodology would otherwise yield. And finally, since its methodology is insensitive to the range of expenditure needs of the poor, its income figures are inadequate for nonpoverty living.

These harsh conclusions are all the more distressing because of their novelty. So few of the policy makers concerned with poverty have neither analyzed the life situation of the poor, nor explored the implications of "poverty definitions" on social policy. is that:

The main assumption on which the Social Security Administration poverty index rests

for individuals, as for nations, . . the proportion of income allotted to the "necessaries," and in particular to food, is an indicator of economic well-being. 2

Accordingly, the government's procedure in determining a poyerty index is to calculate the costs of a food plan-in this case the "economy diet plan"-and then to take a multiple of that cost representing the prevailing proportion of food-to-total expenditure in the general population.

This procedure makes sense only if the food allotment is in fact adequate to meet dietary needs. The "economy plan" is not an adequate diet; it is underpriced in terms of need and, hence, is deceptive as a basis of economic well-being. The economy diet was developed by the Department of Agriculture as a guide for "temporary or emergency use when funds are low." It is a downward modification of the "low cost plan," the minimum diet consistent .with the food preferences of the lowest third of the population and adequate to avoid basic nutritional deficiencies. 3 The economy diet was established because the low-cost plan cost more than public welfare agencies were allotting assistance recipients, and a plan was needed that would serve as a diet guide within the range of assistance payments. 4 The economy diet, pure and simple, is a deficiency diet that exists only because of a deficiency in the public's willingness to maintain assistance payments at the minimum necessary level.

In effect, the use of this economy plan as a measure of the minimum nonpoverty income says that a family living just above this level is still in an emergency situation that should not be maintained over time. To be both above poverty and in an emergency situation with respect to basic food needs suggests that something is seriously wrong with the definition of poverty. If the low-cost plan is. used as the diet component, then the poverty line becomes $\$ 4,005$ and $\$ 2,460$ for nonfarm families and elderly couples, respectively. 5 A comparison of the economy and low-cost plan, as well as the moderate-cost plan, is illustrated in Table 1. 
Besides being deceptive, this poverty measure is unrealistic. Both the economy and the low-cost plan assume skillful, no-waste food preparation, and no deviation from the balance of food items. "The lower the level of cost, the more restricted the kinds and qualities of food must be and the more skill in marketing and food preparation is required."6 That the ideal preparation conditions of the Department of Agriculture can be simulated in the kitchens of the poor is high optimism. But, in addition, there is no reason to believe that low-income people have the skills and nutritional knowledge to adhere to any such food plan. Consumer and home management education has not been and is scarcely now available to low-income people. 7 This failure to recognize a major and relevant deficiency in "community resources" puts the onus on the poor to perform at a level above that of other groups in the society and beyond that for which the society has prepared them.

The poverty free budget assumes maximum shopping effectiveness, for food in particular, but for other goods as well. This too is out of touch with reality. 8 A poor mother cannot afford a baby sitter while she "shops around" in middle-class fashion for the best buys. Indeed, a poverty budget allows little transportation money to leave the neighborhood, hence, shopping choice for food, clothing and durables is all highly restricted. With low, financial resources, a family must often use credit, which of course costs money not allowed for in the budget. To obtain food, poor people may be forced to use the "friendly independent grocery" where credit is available but where prices are usually higher than at the supermarket. The lack of cash reserves means that they are less able than the more affluent to make quantity purchases and to take advantage of special sales. Limited literacy, inability or inexperience in reading the fine print of contracts or labels, and difficulty in mastering various current packaging deceptions all tend to make the low-income consumer an inefficient shopper.

This situation is aggravated by the variety of illegal or quasi-legal practices through which the unscrupulous seek to exploit the poor. Shoddy or misrepresented merchandise, high-pressure selling, loan sharking, "heavy scales," illegal or exorbitant credit charges, repossession procedures undermine the value of the poor man's dollar. This "poverty tax" may make the price he actually pays for goods and services well above the official price quoted to government surveyors and on which the budgets are calculated.

The economy food budget does not allow the cost of any meals eaten away from home. 9 Yet consumption patterns of low-income people indicate numerous meals outside the home. For consumer units with income under $\$ 1000,22$ percent of food expense is outside the home; the figure is 14.3 percent for units with incomes between $\$ 1,000$ and $\$ 2000$, and 18.5 percent for the $\$ 2000$ to $\$ 3,000$ range. 10 These figures reflect the need for lunches at work and at school as well as the need to escape inadequate or tiring kitchen facilities, overcrowded housing, monotonous daily existence, unstable family life or irregular work patterns. Even so, the rates of eating out are less for the poor than for higher-income levels (see Table 3). Again the economy food budget does not seem to be made in terms of the people who must live by it.

This $\$ 3130$ poverty measure is subject to a further shortcoming. In its own terms, it seems to be seriously inaccurate.

The index is based, as noted, on a multiple of the food component of the expenditure pattern of American families. The multiple used is 3-representing a 33.3 percent food-tototal-expenditure ratio. ${ }^{11}$ If this ratio is higher than the data justify, then it would overstate the food component and reciprocally diminish the allotment available to other consumption categories. This seems to be the case.

The figure is based on a 1955 Department of Agriculture study which showed an average food-to-total expenditure ratio of 35 percent. A 1961 Bureau of Labor Statistics study which revealed a much lower 24 percent average was discounted (see Table 2). The preference for the earlier study seems arbitrary. It was suggested that the BLS study tended to understate food expenditures; but this would affect ratio figures only if it also tended to overstate or not similarly understate other expenditures. This was not demonstrated and since the study collected data on expenditures in all categories, not just food, there would seem to be an internal check on the relative figures. Furthermore, comparison of 1950 to 1960-61 BLS studies reflected a decline of 5.6 percent in the ratio within the same methodology. The earlier USDA figure is almost certain to be overstated. 12 
It was noted that given the same per capita income, the spending patterns of different family sizes appear to couverge considerably; hence, certain apparent economies of scale for larger families do not hold up. 13 While this is so, it does not justify the 33 percent figure. This figure is associated with a per capita income in the USDA study of about $\$ 1,300$ and in the BLS study of about $\$ 900$. These per capita figures yield a family income considerably higher than the minimum nonpoverty income.

The expenditures for all consumer units, including individuals as well as families, show a food-to total ratio of 28-30 percent for income ranges under $\$ 3,000$. The 33 percent ratio is thus even higher than the current ratio for all low-income people shown in the BLS survey (see Table 3 ).

Even leaving aside which study more accurately reflects the food-to-total expenditure ratio, both studies use the total expenditure, or after income, as their base. 14 Yet the poverty index is presented as a gross income figure, before social security, property, poll and personal income taxes. This shift in the base would require a compensating decrease in the ratio.

The conclusion is that the 33.3 percent figure is too high and does not in fact represent the criterion of economic well-being it is supposed to measure. A more accurate figure would be no higher than 30 percent, probably less. Recalculating the minimum nonpoverty (four-person, urban) family income gives a rough $\$ 3474$ for the deceptive economy plan and a truer $\$ 4263$ for the low-cost plan.

The final and ultimately most serious problem with this index is that it is inadequate. The food-to-income ratio as a measure of well-being assumes that the expenditure distribution pattern derived from the ratio will be adequate to meet minimum needs at any income level. This assumption is questionable.

Any food-to-total expenditure ratio, derived from aggregate expenditure patterns, is likely to be too high at low income levels. Consumer durables (particularly appliances and furniture) and clothing available at the minimum nonpoverty budget level are of lower quality; they need more frequent repair and replacement. Lower housing quality has the same effect. Thus, low-income people have added costs of property maintenance and replacement not applicable to higher-income purchasers of higher-quality goods. These problems faced by lowincome people require a relative increase in nonfood expenditures, or a downward adjustment in the ratio of food to total-expenditures when it is applied at low-income levels.

A basic need of any family is for contingency resources. In upper-income groups, this presents little problem: More absolute funds are available for discretionary purchases, and adjustments in consumption allocations are possible without reducing any consumption category to the level of privation. In low-income groups, however, with one-third irreducible allocation for food, the absolute amounts available may be insufficient to allow any readjustments for contingencies.

Even more problematic, the absolute funds available in a low-income budget may be insufficient to meet the minimum costs of other irreducible necessities such as housing, clothing and medical care. Given the available supply of goods and prevailing price levels, the absolute budget amounts may not be sufficient to meet minimum family needs, or even to gain access to the supply at all. The absolute income and expenditure requirements of the "modest but adequate" City Worker's Family Budget calculated by the Bureau of Labor Statistics suggest this may be so (see Table 4). Taking only the CWFB figures for rent of nondeteriorated housing, below-average utility costs, and medical care, and adding the economyplan food costs and a minimum income/Social Security tax adjustment leaves only $\$ 400$ a year for all other expenses. Existing expenditure patterns for low-income families demonstrate the extreme inadequacy of this figure (see Table 3).

The failure to determine and calculate the actual costs of the necessary goods and serv: ices for a minimum nonpoverty living standard ties the poverty definition to a food standard. The poverty budget is really a food-maintainence budget-and a deficient one at that. It takes no direct account of other human needs. Thus, it is not only inaccurate in its own terms and unrealistic in terms of the life condition of the poor; it is inadequate for a decent level of living. 
A radically new approach is needed to the definition of poverty-an approach based on social goals and the realities of the social environment. Such a definition would see the poor as having inadequate outside resources to maintain minimum standards of food, shelter, clothing and physical health and to achieve a full development of individual talents and social participation. This "definition" is based on two social goals beyond biological maintenance: individual fulfillment and satisfying involvement in the larger society. These goals relate poverty to a desired quality of life. The productive capacity of the American economy and the potential of our developing technology make these goals possible. No longer can it be argued that a necessity of scarcity restricts them to a privileged few.

Of course, the attainment of these goals is not based simply on the level of family income. Community resources are also important. A community may provide public services which serve as income supplements: medical care, job training, relocation assistance, surplus foods, retirement pension, income maintenance during unemployment or disability, child-care centers, etc. The elimination of poverty in Scandanavian countries, for example, relies heavily on such community income supplements. A community may also provide other resources which serve as adjustment or coping aids which provide an individual or family with needed services or emergency assistance: psychiatric or other counseling, consumer education, legal aid, etc. And, a community may provide a wide opportunity field for individual development and involvement: cultural activities, good schools, adult and remedial education, voluntary organizations, recreation areas, quality housing, public transportation, and an open political structure where people can play meaningful roles in the community.

When viewed in terms of available resources, some communities are poverty-producing; others are poverty-destroying. Resource deficiency handicaps the poverty-freeing potential of income while resource richness decreases the income needed for an adequate life quality. A "Community Resource Scale" should be a component of any adequate measure of poverty.

Whatever the condition of community resources, however, without direct income resources the quality-of-life goals-individual and social development-cannot be attained. The necessary income amount will vary with the stage of the family life-cycle and the stage of the work career, as well as with the community resource richness. The calculation of such an amount as a guide for public policy requires the development of a bill of necessary goods and services for the particular family situation.

\section{Toward the Good Life: An Activity Profile}

What is the income necessary to avoid poverty of life, in contrast to poverty of diet? For what minimum activities must the family have income? The following are illustrative: maintenance of good health and physical functioning; continuing education for self and family; nonwork activity such as reading, crafts, or service; involvement in voluntary organizations; informal social participation, shared meals with friends and relatives, entertainment, television, films and theater; travel within and beyond the immediate community; means of communication with kin and friends.

Without income resources for these sorts of activities, an individual or a family suffers enforced isolation from the values and enriching opportunities of the wider society. Poverty in America involves exclusion from the going social order; it results almost necessarily in undermining socially derived status and sense of personal worth. The destructive effects of poverty are rooted in extremes of social inequality as well as in low levels of income.*

* It has sometimes been said that America's poverty is "rich man's poverty," compared to that of Southeast Asia or tribal Africa.where per capita income is $\$ 50$ to $\$ 75$ per year. American poverty, however, is more destructive to the individual because it is combined with inequality. There is an even more basic differentiation between poverty in America and that of the underdeveloped world. In the highly developed monetary economy of the U.S. land and housing are not free or paid for by sharecropping; food is not communal or self-produced; services and products are not bartered within a community framework of mutual aid. Here, work or production is given somedollar remuneration to make up the price. In this context, the per capita dollar income of many old people, migrant farm or sweat shop workers, or Appalachian poor does not put them in a materially-or socially-better position than that of their brethren in nonmonetary economies. 
In a demand-creating society, socially integrating and personally enriching activities compete for discretionary funds with the more materialistic, status-oriented forms of social integration: expanding clothing wardrobe; style maintenance in automobile, consumer durables, and household furnishings; property improvement, etc. Presumably, material deficiencies in basic, socially publicized standards of quality and convenience will have to be decreased before "nonmaterial" consumption can assume major proportions.

Another feature of the quality-of-life measure can be illustrated by a brief return to an aspect of the food-based budget. In the $\$ 3,130$ nonpoverty budget, a 40 percent downward adjustment is made for farm families to compensate for the fact that, on the average, one-third of their food is home-produced and that their housing costs are met as part of the cost of the farm operation. The quality-of-life standard, however, would involve a subsequent upward adjustment. Farm families need substantially more money for transportation if they are to maintain contact with the wider community; they need opportunities for more structured social and organizational participation, since casual neighboring is more limited in a rural setting; and they need more money for childrearing. The prevailing pattern of farm-to-urban migration suggests that large numbers of farm youth will continue to move to cities. The adequacy of their urban adjustment will depend in large part on the variety of their preurban experience and their preparation for adjustment during their preadult years. Thus, farm families need increased funds for supplementing the usual socialization environment of farm life.

A realistic family budget must be geared to the kind of society in which people live, and to the changes in the society to which they must continually adjust. If the minimum nonpoverty living standard of today is undermined by the technological or social changes of tomorrow, that standard is certainly not adequate. In a society changing as rapidly as ours, money must be spent to prepare the individual and the family for the altered problems and opportunities which can be anticipated in the future.

The definition of poverty clearly requires the development of a list of goods and services adequate to maintain basic material and physiological living conditions, to promote individual development and social integration, and to keep pace with the changing demands and opportuni-. ties of the society. No official agency has attempted to develop such a list. No doubt it would reveal too graphically the inadequacy of the $\$ 3,130$ measure. Its need, however, is not thereby reduced.

\section{How Much Is Enough? The BLS "Modest but Adequate" Budgets}

It is easier to see how much is not enough. Table 3 compares family expenditures for different income levels. The quality-of-life deficiencies of a poor man's budget (columns 2-4) demonstrate clearly that poverty creates social isolation and withdrawal of investment in personal development and education. The items which claim the greatest relative amounts are food, housing, utilities, and medical care. The categories which suffer the greatest loss are reading, education, recreation, transportation, clothing, household furnishings, personal care, personal insurance, gifts and contributions. The dollars available in many of these categories are so few as to represent essentially zero consumption.

The Bureau of Labor Statistics' "modest but adequate" City Workers' Family Budget is the only comprehensive att empt to develop a list of goods and services adequate for an American family. 15 This budget has been computed for 20 cities for a four-member family: a 38-yearold man, his wife, a boy aged 13 and a girl of 8 . A similar budget was developed by the Social Security Administration for an elderly couple in good health 16 (see Tables 4A and 4B). These budgets do not attempt to cover the three standards of adequacy outlined above. Indeed, they impose no external or judgmental standard; they are based solely on existing consumption patterns and consumer preferences.

The city worker needs from $\$ 5642$ to $\$ 6,147$ income before taxes, depending on the city; an elderly couple needs 47-52 percent of the CWFB requirements, or about $\$ 2641$ to $\$ 3366$. A couple might save $\$ 200$ to $\$ 320$ if they own their own home without mortgage. A single retired person needs 70-75 percent as much income as a retired couple. These figures are in terms of 1959 dollars. . The consumer price index has since increased 7.4 percent, suggesting a rough 
adjustment (discounting intercity variation) in the CWFB to $\$ 6054-\$ 6596$ and in the retired couple budget to $\$ 2,833-\$ 3,612$. Table 4 gives these two budgets for selected cities.

Table 5 indicates the relative position of the various cities for which the city worker's budget was computed. Table 6 translates the four-person family budget into equivalent amounts for different size families.

The importance of the CWFB is that it develops a list of goods, services and quantities that approximate an adequate, though modest, living standard. This standard, while above the biological or food-based minimum, is considerably below the average for all American families (compare column 1 in Table 3). As stated by the Social Security Administration:

The level of living represented by the city worker's family budget and the budget for an elderly couple may be described as one providing the goods and services necessary to a healthful, self-respecting mode of living, allowing normal participation in the life of the community in accordance with current American standards. Social and conventional as well as physiological needs are taken into account. 17

In describing the budget, the Monthly Labor Review said:

The budget represents what men commonly expect to enjoy, feel that they have lost status and are experiencing privation if they cannot enjoy, and what they insist on having. Such a budget is not an absolute or unchanging thing. The prevailing judgment of the necessary will vary with the changing values of the community, with the advance of scientific knowledge of human needs, with the productive power of the community and therefore with what people commonly enjoy and see others enjoy. 18

The content of this budget is derived from an analysis of consumer expenditures. The quantities are determined by a "quantity-income elasticity method."

In this technique, the quantities of various items purchased at successive income levels are examined to determine the income level at which the rate of increase in quantities purchased begins to decline in relation to the rate of change in income, i.e., the point of maximum elasticity. The average numbers and kinds of items purchased at these income levels are the quantities specified in the budget. This point has been described as the point on the income scale where families stop buying "more and more" and start buying either "better and better" or something less essential to them. 19

The budget is then priced for each city by sampling a variety of stores and service establishments handling the various budget items. Prices include all state, city and federal taxes.

\section{"Modest but Adequate": What Is Included?}

An identification of the content of this modest living standard will be helpful both in viewing the nature of the deprivation enforced by poverty and the scope of basic needs and activities having monetary equivalence. The $\$ 3,130$ poverty line, or any line, tends to lose meaning because it is hard to keep in mind the range of goods and services that are accepted as a necessary part of American life.

Food and beverage ( $\left.\$ 1,684^{*}\right)$ : The CWFB diet is based on a combination of the Department of Agriculture's moderate plan and low-cost plan. These plans were derived from the food

*Budget amount for Washington, D.C. 
consumption patterns of the middle and lowest third of nonfarm families. Table 1 indicated the content distribution of these diets among the standard food groups and the percent change from one to the other. The food allowance provides 84 meals per week eaten at home by the four-person family, but provision is made for school lunches, lunches at work and 20 other person-meals a year eaten outside the home. There is also $\$ 30$ a year available for snacks or "treats." Beverage allows 173 bottles of beer annually, two fifths of liquor for home consumption and less than half the costs of that liquor for outside consumption.

Housing (\$1470): The family's residence is a five-room, nondeteriorated structure with indoor plumbing. The wife does all the cooking, cleaning and laundry without paid help. The wife does all the cooking, cleaning and laundry without paid help. The home is equipped with a range (replaced every 16.6 years), a refrigerator (every 14.3 years), washing machine (8.3 years), vacuum cleaner, iron and mangle, toaster, hand mixer and sewing machine (with replacements ranging from 8 to 15 years). Expenditure of other equipment is allowed at 11 percent of the annual replacement fund. Furniture is replaced every 6 to 16 years depending on the item. Besides heat and water, utilities include gas, electricity and telephone. A recent study of these costs is summarized in Table 7. The city worker's family is allowed less gas and electricity than the average family.

Clothing (\$554): The wardrobe is not elaborate. For example, for the husband: one topcoat, replaced every five years; three jackets, with ten-year replacement; three suits with four-five-year replacement each; one pair of dress trousers and two work trousers a year; one pair of street shoes a year and a pair of work shoes every two years. Similar variety and durability apply for the children. Twenty garments are sent out to the cleaner each year. Medical and dental care (\$304): This includes hospitalization insurance for the total family in addition to: fifteen office visits, one hospital visit, and one doctor visit at home. Dental care for the family includes an allotment for three dental fillings, one extraction and one and one-half cleanings with an additional 40 percent dental allowance. One surgical expense is allowed every six years, $\$ 13$ is allotted for eye care. The costs of nine prescriptions are included in this amount as well as $\$ 20$ for nonprescription drugs with an additional 4 percent of drug cost for appliances and supplies. $\$ 8.50$ is allowed for other medical care.

Transportation (\$517): Roughly three out of four families have a car, except in New York, Boston and Philadelphia where the ratio is slightly under half. (The ratio is one in five for elderly couples.) This proportion is allowed the purchase of a used four-year-old Chevrolet, Ford or Plymouth every three and one-half years. Nonowners have extra allowance for public transportation: 710 fares a year (two a day) including school fares, plus 244 miles of total travel outside the city.

Reading and recreation (\$212): This includes reading (the cost of a newspaper subscription, $\$ 4.94$ for all nonschool books, $\$ 14.75$ for magazines); recreation (television, radio and phonograph with 10-15 year replacement and only $\$ 1.96$ for yearly repair); movies (28 adult admissions, 25 for the girl, 38 for the boy, plus an additional admissions allowance of 23.8 percent of the above); hobbies (10 percent of above costs); club dues (\$7.17); and toys, sporting goods, pet supplies, etc. (\$46.11).

Personal care (\$127): This includes haircuts (21 for the husband, 14 for the boy and one each for mother and girl) and commodities (soap, toothpaste, shampoo, tissue, cosmetics, shaving supplies, hair permanent supplies plus a 10 percent allowance).

Tobacco (\$75): The family smokes 300 packs per year (six a week), 51 cigars and six two-ounce packages of pipe tobacco. stationery.

Communication (\$85): This allows a telephone, $\$ 8.63$ for postage stamps and $\$ 7.27$ for

Gifts and contributions (\$121): This allows 2.4 percent of total goods and services for Christmas, birthday and other presents to persons outside the immediate family, and contributions to church and charities.

Public school expenses (\$10): This includes textbooks, classroom supplies, laboratory fees and excursions, gymnasium fees, equipment and clothing; school movies and other entertainments in which pupils participate. These costs are calculated on the basis of actual school practices.

Miscellaneous (\$40): This includes lodging away from home, music or dancing lessons for the children, legal expenses, etc. (.8 percent of total goods and services). 
Other cost items and taxes (\$758): Occupational expenses include dues to union, business or professional association, special clothing or equipment that might be required for work (\$28). A life insurance policy provides for family during period of adjustment in event of death of breadwinner $(\$ 110)$. And allowance is made for Social-Security deduction, income and personal taxes.

Poverty and the Modest but Adequate Budget

This BLS city worker's budget does not represent a minimum nonpoverty, quality-of-life budget. There are some areas where it might be economized without substantially reducing the family's well-being or social participation, for example, in food, clothing, house furnishings, haircuts, tobacco, etc. There are other areas where it may be inadequate:

(1) The list of goods and services is developed from current expenditure patterns and does not necessarily represent the allocation needed by poor people to overcome past neglects and achieve effective social integration. Nor may it represent the proper balance of investment in human resources needed by "marginal" families to allow them to keep pace with changing conditions and thus remain above poverty. Furthermore, the distribution of expenses is not necessarily adequate to the current social environment. Increased leisure and rapidly changing job demands suggest the need for greater expenditure on continuing education and preparation for socially productive, noneconomic roles.

(2) For an elderly couple, this problem is particularly striking. A 65-year-old man can expect to live to age 78, a woman, to age 80 and one-half. 20 Investment in personal development and leisure activities should be at a maximum during this period. Yet the budget provides only between $\$ 93$ and $\$ 124$ per year (depending on the city) for reading and recreation$\$ 2$ a week for two people, not even the price of a movie. Whatever its adequacy on other standards, this budget will almost assure social isolation.

(3) A further problem with the elderly couple's budget is that the 10 percent medical item is adequate only for couples who are in good health. "Any major or prolonged illness or disabling condition and all terminal illnesses, often expensive, fall outside the scope of this budget. 21 Thus, even with Medicare, chronic illness may be poverty-producing and the death of one spouse is likely to leave the survivor in poverty.

(4) The city worker's budget provides no savings for emergencies, major illness, or property loss (there is no insurance provision for property inventory), for children's continuing education, for home purchase, or for retirement.

(5) The question of retirement savings illustrates an inconsistency in government standards. In first publishing the elderly couple's budget, the Social Security Administration stated:

The budget is intended to provide a modest but adequate living standard. This does not mean, of course, that this level is thought of as necessarily and in itself determining the goal, in terms of size of payments, toward which those responsible for social and security programs should work. Social insurance benefits represent a substitute for earnings. which are interrupted or cease; it is generally agreed that a man's benefits should be less than what he earned when working. Many individuals have supplementary income from savings, private annuities and other sources. The purpose of public assistance payments is to supplement other income and resources of the needy individual in accordance with the public assistance agency's standards of assistance. 22

Thus, for an elderly couple to maintain even the reduced level of their budget, public policy requires that they have supplementary income. Yet the budget applicable during their working years does not provide for developing savings or retirement income resource. This conflict applies as well to unemployed or disabled workers, to anyone who must leave the work force and rely on public transfer payments.

These several limitations of the modest but adequate budgets obviously apply with even 
greater force to the minimum non-poverty lines of $\$ 3,130$ and $\$ 1,850$ for a nonfarm family and a retired couple. It should be clear, also, that as income falls below the modest BLS levels, it is the consumption in the vital areas of social participation that is the least able to resist cut back: children's participation in school affairs, club dues, church contributions, nonessential transportation, leisure enjoyment, hobbies, etc. The BLS levels much more closely approximate an adequate nonpoverty income measure than do the food derived figures.

What is needed is a minimum list of goods and services which are adequate for family functioning, social involvement, and security in having continuing status in the society. This list and its monetary cost should then be the basis of public policy in confronting the problems of poverty and in setting the levels of public assistance or transfer payments.

When a family does not have enough for a healthful, self-respecting mode of living, then it is poor. One can bicker about how poor and the levels of deprivation might suggest different social policies, but the semantic refinements do not change the reality of social isolation and inequality.

\section{FOOTNOTES}

1. Mollie Orshansky, "Counting the Poor: Another Look at the Poverty Profile," Social Security Bulletin, Vol. 28, No. 1, January 1965. Table E, p. 28 (cited as

"Orshansky").

2. Orshansky, p. 7 .

3. E. Cofer, E. Grossman, F. Clark, "Family Food Plans and Costs," United States Department of Agriculture Home Economics Research Report No. 20, 1962 .

4. Orshansky, p. 6 .

5. Orshansky, p. 28, Table E.

6. Orshansky, p. 5 .

7. Consumers Union of the United States, Inc., "Consumer Education for Low-Income Families," July 1964.

8. David Caplovitz, The Poor Pay More, New York: The Free Press, 1963, Chapter II.

9. Orshansky, p. 10 .

10. Bureau of Labor Statistics, Consumer Expenditures and Income, Urban United States, 1960-61, Supplement 3-Part A to BLS Report 237-38, Table 29A, July 1964 (cited as "Consumer Expenditures").

11. Orshansky, p. 9.

12. Bureau of Labor Statistics, Consumer Expenditures and Income, BLS Report 237-34, May 1964, p. 2.

13. Orshansky, p. 8.

14. Consumer Expenditures, p. 163.

15. Helen H. Lamale and Margaret S. Stotz, "The Interim City Worker's Family Budget," Monthly Labor Review, August 1960, Reprint \#2346. See also, "Budget for a Self-Supporting Working Woman, "Industrial Welfare Commission, State of California, December 1961. 
16. Mollie Orshansky, "Budgets for an Elderly Couple: Interim Revision by the Bureau of Labor Statistics," Social Security Bulletin, December 1960 (cited as "Elderly Budget").

17. Elderly Budget, p. 20-27.

18. Department of Labor, "The City Worker's Family Budget," Monthly Labor Review, February 1948, p. 137.

19. Elderly Budget, p. 34 .

20. United States Senate, The Aged in the United States. Hearings before the Subcommittee on Problems of the Aged and Aging, Committee on Labor and Public Welfare, June 16-18, 1959 , p. 8.

21. Elderly Budget, p. 35 .

22. Elderly Budget, p. 27. 


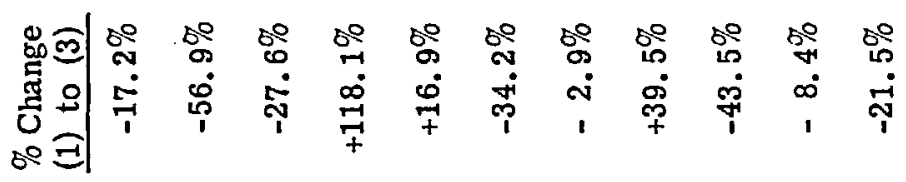

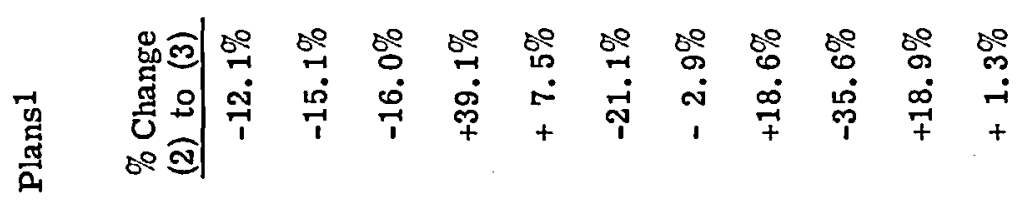

尊

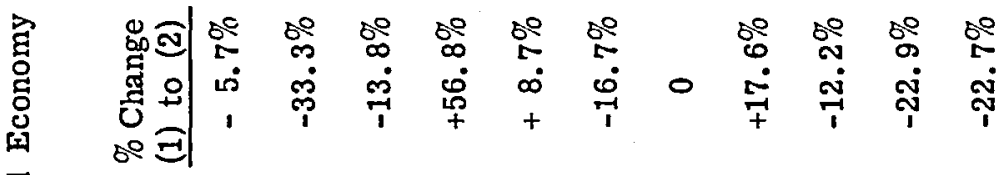

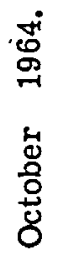

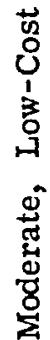

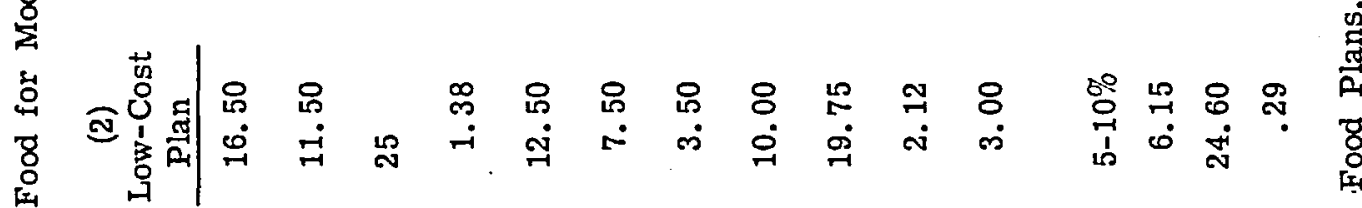

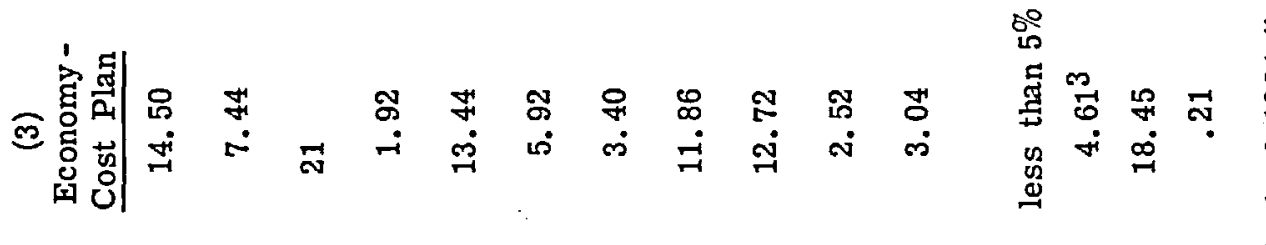
$\frac{2}{2}$

응

营

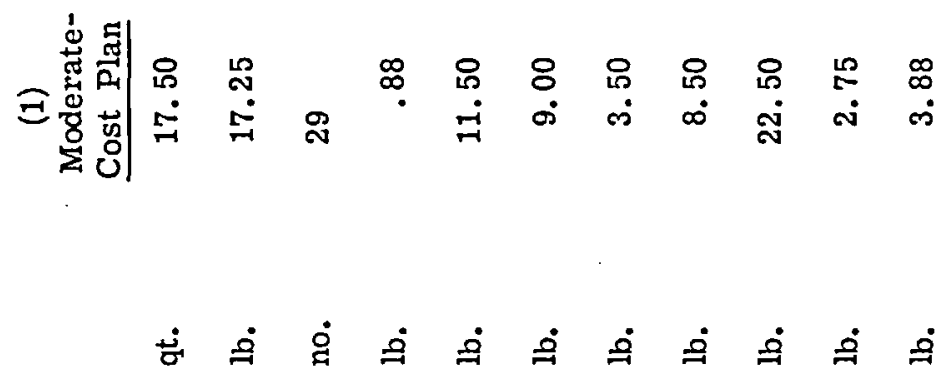

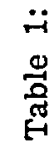

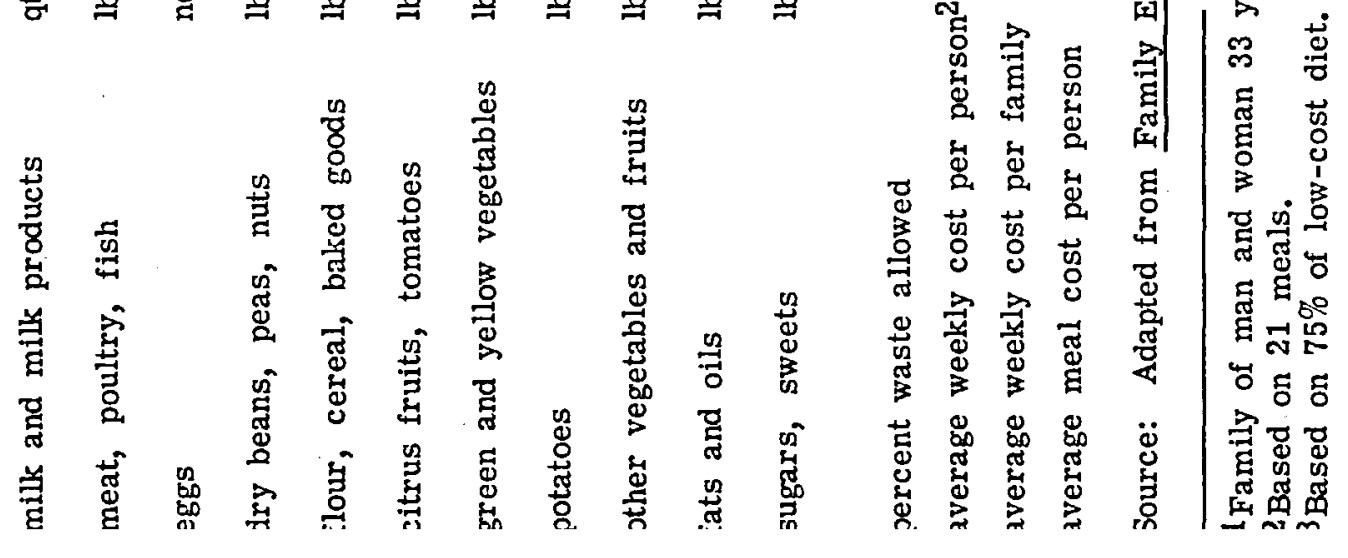


Table 2A. Food-Income Relationships Among Nonfarm Consumers: Per capita income, 1 per capita food expenditures, 2 and portion of income spent on food by income class and size of consumer unit, nonfarm households, 1955

\begin{tabular}{|c|c|c|c|c|c|c|}
\hline \multirow[b]{2}{*}{ Money income (after taxes) } & \multicolumn{6}{|c|}{ Number of persons in unit } \\
\hline & 2 & 3 & 4 & 5 & 6 & $\begin{array}{l}7 \text { or } \\
\text { more }\end{array}$ \\
\hline \multicolumn{7}{|l|}{ Total: } \\
\hline Per capita income & $\$ 2,036$ & $\$ 1,603$ & $\$ 1,296$ & $\$ 1,067$ & $\$ 837$ & $\$ 615$ \\
\hline Per capita expenditure for food & $\$ 550$ & $\$ 497$ & $\$ 454$ & $\$ 384$ & $\$ 335$ & $\$ 283$ \\
\hline Food as percent of income & 27 & 31 & 35 & 36 & 40 & \\
\hline \multicolumn{7}{|l|}{ Less than $\$ 2,000$ : } \\
\hline Per capita income & $\$ 524$ & $\$ 419$ & $\$ 331$ & $\$ 240$ & $\$ 240$ & $\$ 156$ \\
\hline Per capita expenditure for food & $\$ 316$ & $\$ 307$ & $\$ 275$ & $\$ 196$ & $\$ 154$ & $\$ 141$ \\
\hline Food as percent of income & 60 & 73 & 83 & 81 & 64 & 90 \\
\hline \multicolumn{7}{|l|}{$\$ 2,000-2,999:$} \\
\hline Per capita income & $\$ 1,250$ & $\$ 834$ & $\$ 630$ & $\$ 513$ & $\$ 430$ & $\$ 314$ \\
\hline Per capita expenditure for food & $\$ 456$ & $\$ 424$ & $\$ 331$ & $\$ 298$ & $\$ 296$ & $\$ 199$ \\
\hline Food as percent of income & 36 & 51 & 52 & 58 & 69 & 63 \\
\hline \multicolumn{7}{|l|}{$\$ 3,000-3,999:$} \\
\hline Per capita income & $\$ 1,738$ & $\$ 1,162$ & $\$ 882$ & $\$ 707$ & $\$ 588$ & $\$ 466$ \\
\hline Per capita expenditure for food & $\$ 564$ & $\$ 441$ & $\$ 397$ & $\$ 327$. & $\$ 291$ & $\$ 248$ \\
\hline Food as percent of income & 32 & 38 & 45 & 46 & 49 & 54 \\
\hline \multicolumn{7}{|l|}{$\$ 4,000-4,999:$} \\
\hline Per capita income & $\$ 2,242$ & $\$ 1,496$ & $\$ 1,121$ & $\$ 901$ & $\$ 751$ & $\$ 605$ \\
\hline Per capita expenditure for food & $\$ 576$ & $\$ 510$ & $\$ 432$ & $\$ 388$ & $\$ 350$ & $\$ 264$ \\
\hline Food as percent of income & 26 & 34 & 38 & 43 & 47 & 44 \\
\hline \multicolumn{7}{|l|}{$\$ 5,000-5,999:$} \\
\hline Per capita income & $\$ 2,719$ & $\$ 1,815$ & $\$ 1,363$ & $\$ 1,102$ & $\$ 897$ & $\$ 685$ \\
\hline Per capita expenditure for food & $\$ 655$ & $\$ 551$ & $\$ 454$ & $\$ 404$ & $\$ 344$ & $\$ 327$ \\
\hline Food as percent of income & 24 & 30 & 33 & 37 & 38 & 48 \\
\hline \multicolumn{7}{|l|}{$\$ 6,000-7,999$} \\
\hline Per capita income & $\$ 3,352$ & $\$ 2,246$ & $\$ 1,695$ & $\$ 1,351$ & $\$ 1,146$ & $\$ 901$ \\
\hline Per capita expenditure for food & $\$ 720$ & $\$ 582$ & $\$ 527$ & $\$ 435$ & $\$ 386$ & $\$ 383$ \\
\hline Food as percent of income & 21 & 27 & 31 & 32 & 34 & 42 \\
\hline \multicolumn{7}{|l|}{$\$ 8,000-9,999:$} \\
\hline Per capita income & $\$ 4,449$ & $\$ 2,915$ & $\$ 2, .187$ & $\$ 1,777$ & $\$ 1,485$ & $\$ 1,117$ \\
\hline Per capita expenditure for food & $\$ 773$ & $\$ 616$ & $\$ 564$ & $\$ 513$ & $\$ 411$ & $\$ 339$ \\
\hline Food as percent of income & 17 & 21 & 26 & 29 & 28 & 30 \\
\hline \multicolumn{7}{|l|}{$\$ 10,000$ or more: } \\
\hline Per capita income & $\$ 7,321$ & $\$ 5,713$ & $\$ 3,854$ & $\$ 3,238$ & $\$ 2,515$ & $\$ 2,017$ \\
\hline Per capita expenditure for food & $\$ 1,047$ & $\$ 901$ & $\$ 714$ & $\$ 643$ & $\$ 597$ & $\$ 398$ \\
\hline Food as percent of income & 19 & 16 & 18 & 20 & 24 & 20 \\
\hline
\end{tabular}

1. Income after taxes.

2 Including alcoholic beverages.

Source: Derived from U.S. Department of Agriculture, Household Food Consumption Survey, 6

1955, Food Consumption in the United States (Report No. 1), December 1956. 
Table 2B. Food-Income Relationships Among Urban Consumers: Per capita income, ${ }^{1}$ per capita food expenditures, ${ }^{2}$ and portion of income spent on food, by income class and size of consumer unit, urban households, 1960-61

\begin{tabular}{|c|c|c|c|c|c|c|}
\hline \multirow[b]{2}{*}{ Money income (after taxes) } & \multicolumn{6}{|c|}{ Number of persons in unit } \\
\hline & 1 & 2 & 3 & 4 & 5 & $\begin{array}{l}6 \text { or } \\
\text { more }\end{array}$ \\
\hline Total: & & & & & & \\
\hline Per capita income & $\$ 2,967$ & $\$ 2,750$ & $\$ 2,302$ & $\$ 1,854$ & $\$ 1,512$ & $\$ 1,034$ \\
\hline Per capita expenditure for food & $\$ 680$ & $\$ 591$ & $\$ 495$ & $\$ 426$ & $\$ 378$ & $\$ 295$ \\
\hline Food as percent of income & 23 & 22 & 22 & 24 & 26 & 28 \\
\hline Less than $\$ 1,000$ : & & & & & & \\
\hline Per capita income & $\$ 755$ & $\$ 333$ & ()$^{3}$ & (') & (') & (') \\
\hline Per capita expenditure for food & $\$ 322$ & $\$ 273$ & (') & $(')$ & (') & (') \\
\hline Food as percent of income & 43 & 78 & (') & (') & ( & (') \\
\hline$\$ 1,000-1,999:$ & & & & & & \\
\hline Per capita income & $\$ 1,487$ & $\$ 860$ & $\$ 551$ & $\$ 410$ & $\$ 281$ & (') \\
\hline Per capita expenditure for food & $\$ 468$ & $\$ 323$ & $\$ 212$ & $\$ 156$ & $\$ 125$ & (') \\
\hline Food as percent of income & 32 & 38 & 38 & 39 & 46 & (') \\
\hline$\$ 2,000-2,999:$ & & & & & & \\
\hline Per capita income & $\$ 2,525$ & $\$ 1,265$ & $\$ 868$ & $\$ 651$ & $\$ 550$ & $\$ 373$ \\
\hline Per capita expenditure for food & $\$ 648$ & $\$ 385$ & $\$ 269$ & $\$ 258$ & $\$ 209$ & $\$ 171$ \\
\hline Food as percent of income & 28 & 31 & 32 & 40 & 39 & 46 \\
\hline$\$ 3,000-3,999:$ & & & & & & \\
\hline Per capita income & $\$ 3,497$ & $\$ 1,786$ & $\$ 1,190$ & $\$ 908$ & $\$ 723$ & $\$ 495$ \\
\hline Per capita expenditure for food & $\$ 793$ & $\$ 487$ & $\$ 354$ & $\$ 293$ & $\$ 275$ & $\$ 185$ \\
\hline Food as percent of income & 23 & 27 & 31 & 33 & 38 & 37 \\
\hline$\$ 4,000-4,999:$ & & & & & & \\
\hline Per capita income & $\$ 4,457$ & $\$ 2,350$ & $\$ 1,552$ & $\$ 1,175$ & $\$ 915$ & $\$ 678$ \\
\hline Per capita expenditure for food & $\$ 942$ & $\$ 544$ & $\$ 401$ & $\$ 332$ & $\$ 291$ & $\$ 235$ \\
\hline Food as percent of income & 21 & 23 & 27 & 29 & 32 & 35 \\
\hline$\$ 5,000-5,999:$ & & & & & & \\
\hline Per capita income & $\$ 5,425$ & $\$ 2,796$ & $\$ 1,881$ & $\$ 1,400$ & $\$ 1,102$ & $\$ 797$ \\
\hline Per capita expenditure for food & $\$ 978$ & $\$ 582$ & $\$ 442$ & $\$ 367$ & $\$ 310$ & $\$ 260$ \\
\hline Food as percent of income & 18 & 22 & 24 & 27 & 29 & 33 \\
\hline$\$ 6,000-7,499:$ & & & & & & \\
\hline Per capita income & $\$ 6,737$ & $\$ 3,392$ & $\$ 2,259$ & $\$ 1,695$ & $\$ 1,370$ & $\$ 1,001$ \\
\hline Per capita expenditure for food & $\$ 1,305$ & $\$ 690$ & $\$ 505$ & $\$ 427$ & $\$ 372$ & $\$ 293$ \\
\hline Food as percent of income & 19 & 20 & 23 & 25 & 27 & 29 \\
\hline$\$ 7,500-9,999:$ & & & & & & \\
\hline Per capita income & $\$ 8,537$ & $\$ 4,262$ & $\$ 2,902$ & $\$ 2,162$ & $\$ 1,729$ & $\$ 1,260$ \\
\hline Per capita expenditure for food & $\$ 1,314$ & $\$ 805$ & $\$ 609$ & $\$ 494$ & $\$ 436$ & $\$ 347$ \\
\hline Food as percent of income & 15 & 19 & 22 & 23 & 26 & 28 \\
\hline$\$ 10,000-14,999$ & & & & & & \\
\hline Per capita income & (') & $\$ 5,880$ & $\$ 3,962$ & $\$ 2,990$ & $\$ 2,392$ & $\$ 1,636$ \\
\hline Per capita expenditure for food & (') & $\$ 934$ & $\$ 717$ & $\$ 601$ & $\$ 494$ & $\$ 398$ \\
\hline Food as percent of income & (') & 17 & 19 & 21 & 22 & 24 \\
\hline$\$ 15,000$ or more: & & & & & & \\
\hline Per capita income & (') & $\$ 11,544$ & $\$ 7,445$ & $\$ 5,733$ & $\$ 4,356$ & $\$ 2,867$ \\
\hline Per capita expenditure for food & (') & $\$ 1,352$ & $\$ 888$ & $\$ 725$ & $\$ 719$ & $\$ 537$ \\
\hline Food as percent of income & (') & 12 & 12 & 13 & 17 & 19 \\
\hline
\end{tabular}

1 Income after taxes and other money receipts.

2 Including all purchased food and beverages consumed at home or away from home.

3 Not shown where size of sample under 20 .

Source: Derived from Bureau of Labor Statistics, Report No. 237-38, Consumer Expenditures and Incomes, July 1964. 
MONEY INCOME AFTER TAXES

$\$ 1,000 \$ 2,000 \$ 3,000 \$ 4,000 \$ 5,000 \$ 6,000 \$ 7,500 \$ 10,000 \$ 15,000$

Family Characteristic

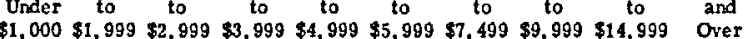

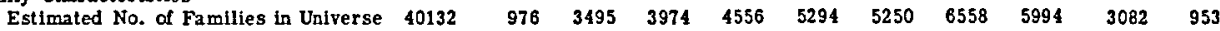

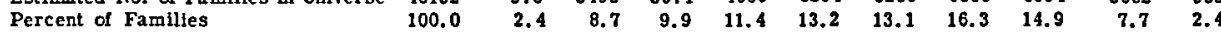
Average

Family Size

Money Income Before Taxes

Net Change in Assets and Liabilities

$\begin{array}{lllllllllll}3.1 & 1.3 & 1.7 & 2.3 & 2.6 & 3.1 & 3.4 & 3.6 & 3.8 & 4.0 & 3.7\end{array}$

Number of Full-Time Earners

Age of Head

Education of Head

Number of Chlldren Under 18 Years

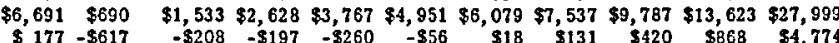

$\begin{array}{rrrrrrrrrrr}.8 & .1 & .1 & .4 & .6 & .8 & .9 & 1.1 & 1.2 & 1.4 & 1.2 \\ 47 & 67 & 62 & 53 & 47 & 44 & 42 & 43 & 44 & 47 & 51 \\ 11 & 7 & 8 & 9 & 10 & 10 & 11 & 11 & 12 & 13 & 14 \\ 1.2 & .2 & .3 & .7 & .9 & 1.2 & 1.4 & 1.5 & 1.5 & 1.5 & 1.1\end{array}$
Percent

Homeowners, All Year

Auto Owners, End of Year

Nonwhite

Reporting Savings Increase Decrease No Change

With Children Under 18 Years

With Persons 65 Years and Over

$\begin{array}{rrrrrrrrrrr}\mathbf{5 3} & \mathbf{4 1} & \mathbf{3 6} & \mathbf{3 7} & \mathbf{3 7} & \mathbf{4 1} & \mathbf{5 1} & \mathbf{6 5} & \mathbf{7 0} & \mathbf{7 7} & \mathbf{8 6} \\ \mathbf{7 3} & \mathbf{1 5} & \mathbf{1 8} & \mathbf{4 0} & \mathbf{6 2} & \mathbf{7 7} & \mathbf{8 6} & 90 & 94 & 96 & \mathbf{9 5} \\ \mathbf{1 2} & \mathbf{1 9} & \mathbf{2 7} & \mathbf{2 1} & \mathbf{1 9} & \mathbf{1 3} & \mathbf{1 0} & \mathbf{7} & \mathbf{5} & \mathbf{4} & \mathbf{1} \\ \mathbf{5 2} & \mathbf{1 5} & \mathbf{2 5} & \mathbf{3 9} & \mathbf{4 0} & \mathbf{5 2} & \mathbf{5 6} & \mathbf{6 1} & 66 & \mathbf{6 7} & \mathbf{7 7} \\ \mathbf{4 1} & \mathbf{5 5} & \mathbf{4 9} & \mathbf{4 9} & \mathbf{5 1} & \mathbf{4 5} & \mathbf{4 1} & \mathbf{3 7} & \mathbf{3 3} & \mathbf{3 2} & \mathbf{2 0} \\ \mathbf{7} & \mathbf{3 0} & \mathbf{2 6} & \mathbf{1 3} & 10 & \mathbf{4} & \mathbf{3} & \mathbf{2} & 1 & 1 & \mathbf{3} \\ \mathbf{5 0} & 6 & \mathbf{1 5} & 28 & \mathbf{4 0} & \mathbf{5 2} & \mathbf{6 1} & 64 & 66 & 63 & \mathbf{5 2} \\ \mathbf{2 3} & \mathbf{6 3} & \mathbf{6 1} & \mathbf{3 8} & \mathbf{2 5} & \mathbf{1 7} & \mathbf{1 3} & \mathbf{1 0} & \mathbf{1 3} & \mathbf{1 5} & \mathbf{2 1}\end{array}$

Average Income, Expenditures and Savings Total Receipts

Money Income After Taxes

Oher Money Receipts

Decrease in Assets

Increase in Liabilities

Account Balancing Difference

Total Disbursements

Increase in

Decrease in Liabilities

Personal Insurance

Gifts and Contributions

Expenditures for Current Consumption

Food, Total

Food Prepared at Home

Food Axay from Home

Tobacco

Alcoholic Beverages

Housing, Total

Shelter

Rented Drelling

Owned Drelling

Oher Shelter

Fuel, Light, Refrigeration, Water

Household Operations

Housefurnishings and Equipment
Clothing, Clothing Mfaterials, Services 55

$\$ 7,747 \$ 1,702 \$ 2,081 \$ 3,292 \$ 4,723 \$ 5,927 \$ 7,085 \$ 8,931 \$ 10,916 \$ 15,359 \$ 28,789$

$\begin{array}{lllllllllll}5,906 & 654 & 1,513 & 2,508 & 3,516 & 4,506 & 5,495 & 6,710 & 8,573 & 11,724 & 21,889\end{array}$

$\begin{array}{rrrrrrrrrrr}82 & 84 & 65 & 49 & \mathbf{4 7} & 130 & 86 & 71 & 48 & 96 & 383 \\ 897 & 909 & 398 & 476 & 672 & 599 & 617 & 898 & 1,018 & 1,995 & 4,434 \\ 862 & 55 & 105 & 259 & 488 & 692 & 887 & 1,252 & 1,277 & 1,544 & 2,083\end{array}$

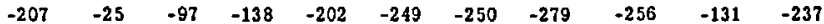

$\begin{array}{lllllllllll}7,954 & 1,727 & 2,178 & 3,430 & 4,925 & 6,176 & 7,335 & 9,210 & 11,172 & 15,490 & 29,026\end{array}$

$\begin{array}{lllllllllll}1,423 & 307 & 239 & 398 & 602 & 896 & 1,035 & 1,570 & 1,947 & 3,284 & 9,831\end{array}$

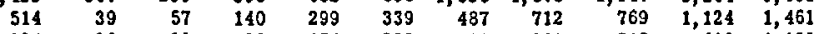

$\begin{array}{rrrrrrrrrrr}\mathbf{3 2 4} & 26 & 39 & 90 & 154 & 239 & 303 & 389 & 515 & 698 & 1,199 \\ \mathbf{3 0 3} & \mathbf{4 8} & \mathbf{7 3} & \mathbf{1 2 7} & 154 & 201 & 270 & 310 & 407 & 640 & 1,790\end{array}$

$\begin{array}{lllllllllll}5,390 & 1,307 & 1,770 & 2,675 & 3,716 & 4,501 & 5,240 & 6,229 & 7,534 & 9,744 & 14,745\end{array}$

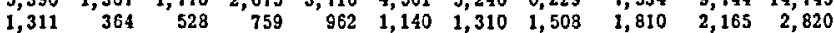

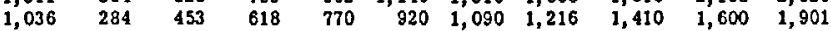

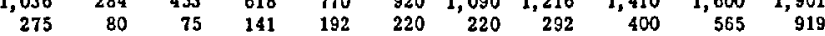

$\begin{array}{rrrrrrrrrrr}275 & 80 & 75 & 141 & 192 & 220 & 220 & 292 & 400 & 565 & 919 \\ 95 & 21 & 32 & 56 & 79 & 93 & 104 & 117 & 127 & 125 & 147\end{array}$

\begin{tabular}{rrrrrrrrrrr}
90 & 9 & 20 & 33 & 57 & 74 & 84 & 107 & 132 & 184 & 275 \\
\hline 588 & 533 & 691 & 912 & 1,164 & 1,338 & 1,554 & 1,816 & 2,083 & 2,630 & 4,373
\end{tabular}

$\begin{array}{rrrrrrrrrrr}1,588 & 533 & 691 & 912 & 1,164 & 1,338 & 1,554 & 1,816 & 2,083 & 2,630 & 4,373 \\ 748 & 314 & 383 & 495 & 584 & 651 & 737 & 843 & 943 & 1,140 & 1,841\end{array}$

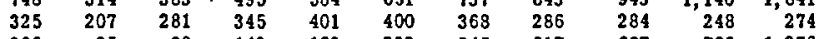

$\begin{array}{lllllllllll}385 & 95 & 98 & 142 & 169 & 232 & 345 & 517 & 607 & 785 & 1,276\end{array}$

$\begin{array}{rrrrrrrrrrr}38 & 12 & 4 & 8 & 14 & 19 & 24 & 40 & 52 & 107 & 291 \\ 244 & 102 & 129 & 155 & 181 & 212 & 251 & 281 & 318 & 368 & 488\end{array}$

$\begin{array}{lllllllllll}319 & 77 & 115 & 159 & 224 & 255 & 289 & 348 & 418 & 597 & 1,261\end{array}$

Persomal Care

Medical Care

Recreation

Reading

Education

Transportation

Automobile

Oher Travel and Transportation

Other Expenditures

418
404

$525 \quad 783$

$\begin{array}{lllllll}62 & 108 & 219 & 336 & 437 & 517 & 642\end{array}$

$\begin{array}{rrrrrrr}33 & 52 & 88 & 117 & 133 & 158 & 177 \\ 121 & 141 & 218 & 272 & 284 & 341 & 405\end{array}$

840
215

$\begin{array}{rr}1,157 & 1,813 \\ 263 & 348\end{array}$

$\begin{array}{lll}478 & 598 & 917\end{array}$

$\begin{array}{lll}337 & 483 & 671\end{array}$

$\begin{array}{rrrrrrrr}13 & 18 & 26 & 34 & 41 & 46 & 57 \\ 22 & 6 & 12 & 22 & 26 & 39 & 59\end{array}$

$\begin{array}{rrr}67 & 94 & 126 \\ 85 & 196 & 421\end{array}$

$1,207 \quad 1,596 \quad 2,101$

$809 \quad 953 \quad 1,207$

$\begin{array}{ll}1,596 & 2,101 \\ 1,401 & 1,605\end{array}$

419620

Value of Items Received without Expense Food

Sheiter

Other

$\begin{array}{llll}119 & 38 & 42 & 50\end{array}$

$114 \quad 195 \quad 495$

$\begin{array}{lllllllllll}202 & 149 & 197 & 152 & 178 & 175 & 216 & 213 & 220 & 265 & 305\end{array}$

$\begin{array}{rrrrrrrrrrr}14 & 36 & 26 & 17 & 12 & 13 & 11 & 12 & 10 & 14 & 15 \\ 11 & 21 & 37 & 11 & 15 & 9 & 12 & 3 & 4 & 4 & 6 \\ 177 & 92 & 134 & 124 & 151 & 153 & 193 & 198 & 206 & 247 & 284\end{array}$

Percent Distribution

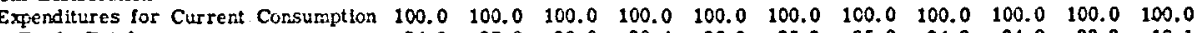

$\begin{array}{lllllllllll}24.3 & 27.8 & 29.8 & 28.4 & 25.9 & 25.3 & 25.0 & 24.2 & 24.0 & 22.2 & 19.1\end{array}$

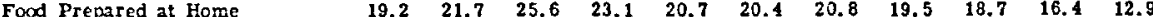

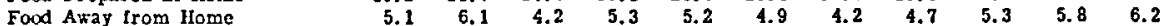

Alcoholic Beverages

Housing, Total

Shelter

Rented Dwelling

Owned Dwelling

Other Shelter

Fuel, Light, Refrigeration, water

Household Operations

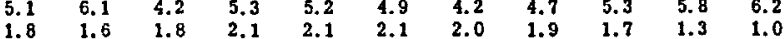

$\begin{array}{rrrrrrrrrrr}1.8 & 1.6 & 1.8 & 2.1 & 2.1 & 2.1 & 2.0 & 1.9 & 1.7 & 1.3 & 1.0 \\ 1.7 & .7 & 1.1 & 1.2 & 1.5 & 1.6 & 1.6 & 1.7 & 1.8 & 1.9 & 1.9\end{array}$

$\begin{array}{lllllllllll}29.5 & 40.6 & 39.0 & 34.1 & 31.3 & 29.7 & 29.7 & 29.1 & 27.6 & 27.0 & 29.6 \\ 13.9 & 24.0 & 21.6 & 18.5 & 15.7 & 14.5 & 14.1 & 13.5 & 12.5 & 11.7 & 12.5\end{array}$

$3.82 .5 \quad 1.9$

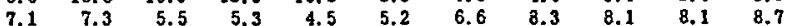

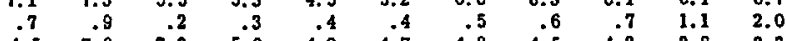

Housefurnishings and Equipment

$5.8 \quad 4.9$

$\begin{array}{llllll}5.9 & 5.9 & 6.5 & 5.9 & 6.0 & 5.7\end{array}$

Clothing, Clothing Mtaterials, Services 10

$\begin{array}{lll}4.2 & 3.8 & 3.3\end{array}$

Personal Care

Medical Care

Recreation

Reading

Education

Transportation

Automoblle

Oher Travel and Transportation

Other Expenditures

$\begin{array}{lllllll}2.9 & 4.7 & 6.1 & 8.2 & 9.0 & 9.7 & 9.9 \\ 6.5 & 2.5 & 2.9 & 3.3 & 3.1 & 3.0 & 3.0\end{array}$

$\begin{array}{lllll}5.3 & 5.5 & 5.4 & 5.4 & 5.3\end{array}$

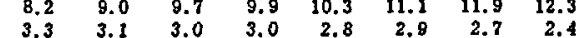

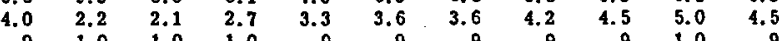

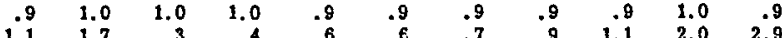

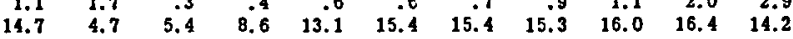

$\begin{array}{lllllllllll}13.0 & 2.2 & 3.4 & 6.5 & 11.3 & 13.8 & 14.1 & 13.9 & 14.5 & 14.4 & 10.9\end{array}$

$\begin{array}{lllllllllll}1.7 & 2.5 & 2.0 & 2.1 & 1.8 & 1.6 & 1.3 & 1.4 & 1.5 & 2.0 & 3.4 \\ 2.2 & 2.8 & 2.4 & 1.9 & 1.7 & 1.8 & 1.7 & 2.1 & 2.0 & 2.6 & 5.0\end{array}$ 


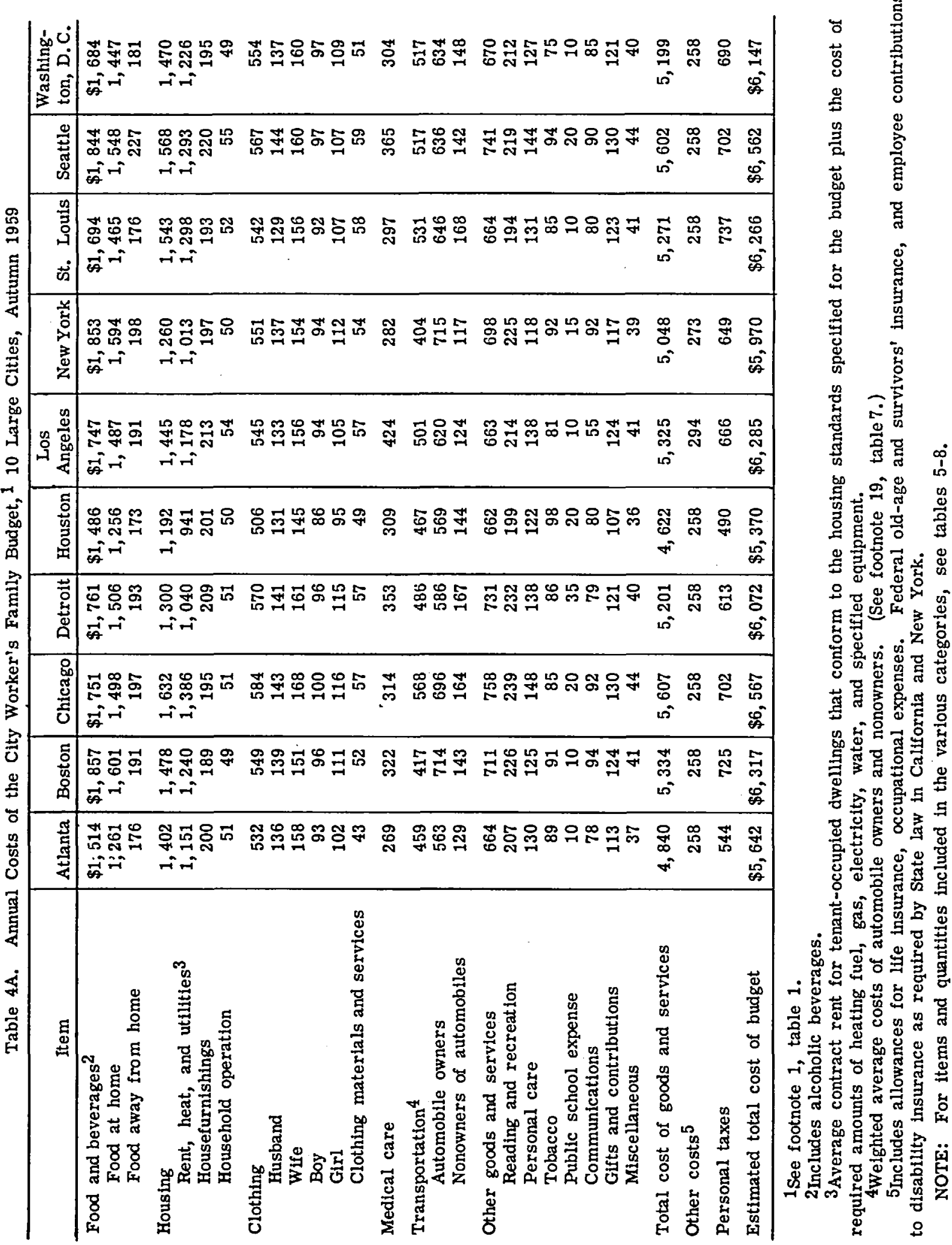




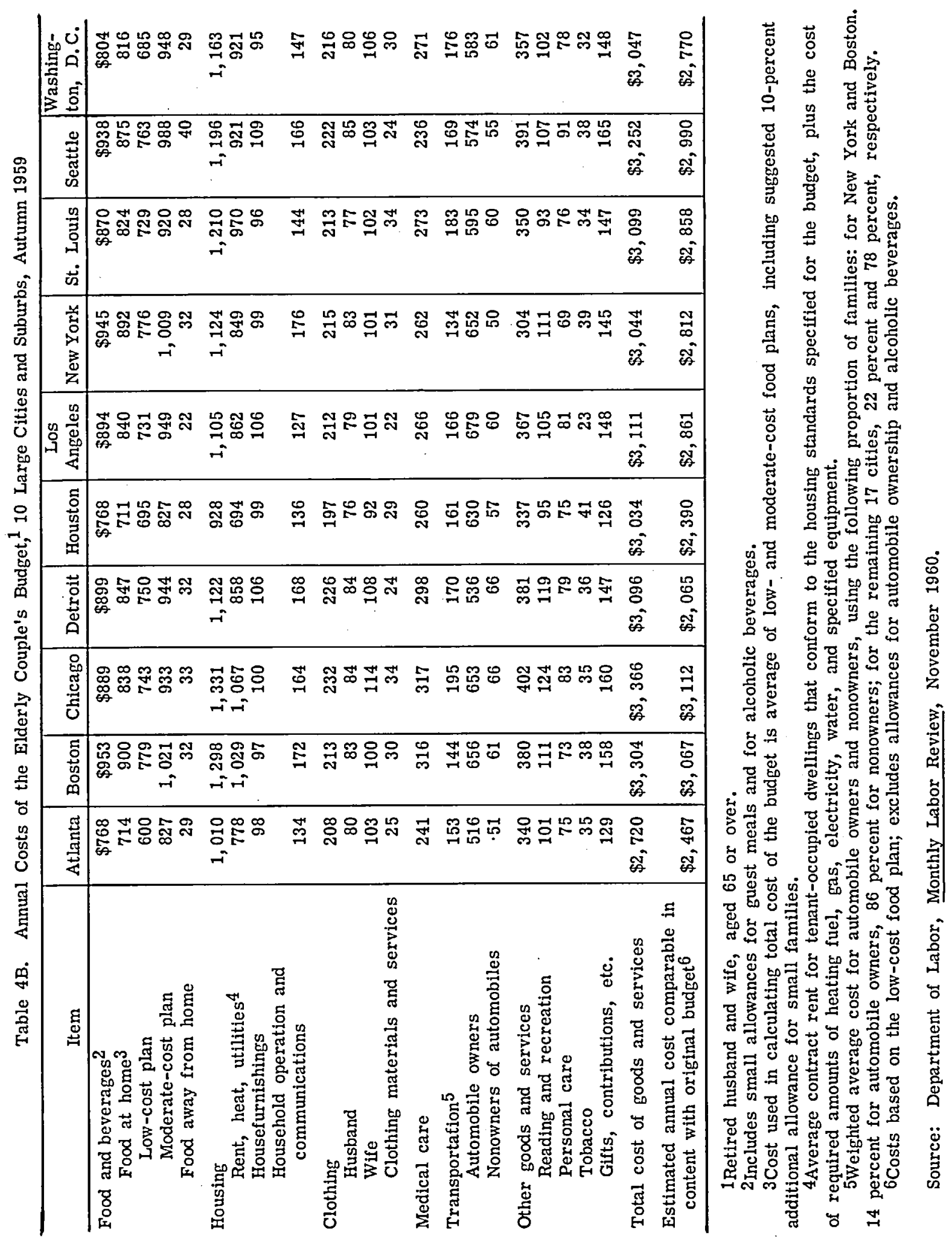


Table 5. Relative Intercity Differences in the Costs of the City Worker's Family Budget, 10 Large Cities and Suburbs, Autumn 1959*

\begin{tabular}{|c|c|c|c|c|c|}
\hline \multirow[b]{2}{*}{ City } & \multirow[b]{2}{*}{$\begin{array}{l}\text { Total } \\
\text { Budget }\end{array}$} & \multicolumn{4}{|c|}{ Goods, rents, and services } \\
\hline & & Total & $\begin{array}{l}\text { Food and } \\
\text { beverages }\end{array}$ & $\begin{array}{c}\text { Rent, } \\
\text { heat, and } \\
\text { utilities }\end{array}$ & $\begin{array}{l}\text { Other } \\
\text { goods and } \\
\text { services }\end{array}$ \\
\hline Atlanta & 92 & 93 & 90 & 94 & 95 \\
\hline Boston & 103 & 103 & 110 & 101 & 98 \\
\hline Chicago & 107 & 108 & -- & 113 & 108 \\
\hline Detroit & 99 & 100 & 105 & 85 & 105 \\
\hline Houston & 87 & 89 & 88 & 77 & 96 \\
\hline Los Angeles & 102 & 102 & 104 & 96 & 105 \\
\hline New York & 97 & 97 & 110 & 83 & 95 \\
\hline St. Louis & 102 & 101 & 101 & 106 & 100 \\
\hline Seattle & 107 & 108 & 110 & 105 & 108 \\
\hline Washington, D.C. & 100 & 100 & 100 & 100 & 100 \\
\hline
\end{tabular}

* Washington, D. C. - 100

Table 6. Estimated Annual Cost of Goods and Services Providing the Same Level of Well-being Among Families of Different Sizes, 110 Large Cities and Suburbs, Autumn, 1959

\begin{tabular}{l|c|c|c|c}
\hline \multicolumn{1}{c|}{ City } & $\begin{array}{c}\text { Estimated } \\
2 \text {-person }\end{array}$ & $\begin{array}{l}\text { Estimated } \\
\text { 3-person }\end{array}$ & $\begin{array}{c}\text { CWFB } \\
\text { cost for } \\
\text { 4-person }\end{array}$ & $\begin{array}{c}\text { Estimated } \\
\text { 5-person }\end{array}$ \\
\hline Atlanta & $\$ 3,194$ & $\$ 4,211$ & $\$ 4,840$ & $\$ 5,808$ \\
Boston & 3,520 & 4,641 & 5,334 & 6,401 \\
Chicago & 3,701 & 4,878 & 5,607 & 6,728 \\
Detroit & 3,433 & 4,525 & 5,201 & 6,241 \\
Houston & 3,051 & 4,021 & 4,622 & 5,546 \\
Los Angeles & 3,514 & 4,633 & 5,325 & 6,390 \\
New York & 3,332 & 4,392 & 5,048 & 6,058 \\
St. Louis & 3,479 & 4,586 & 5,271 & 6,325 \\
Seattle & 3,697 & 4,874 & 5,602 & 6,722 \\
Washington, D.C. & 3,431 & 4,523 & 5,199 & 6,239 \\
\hline
\end{tabular}

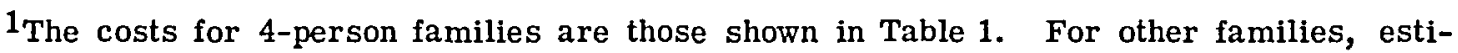
mates are based on the equivalent income scales shown in text below.

The head of all these families is age 35-55, and the family composition is as follows:

2-person: Husband and wife.

3-person: Husband and wife, 1 child between 6-16 years.

4-person: Husband and wife, 2 children, oldest between 6-16 years.

5-person: Husband and wife, 3 children, oldest between 6-16 years. 
Table 7. Representative Utility Costs 1

\begin{tabular}{|c|c|c|c|c|c|c|c|c|c|}
\hline 忌 & 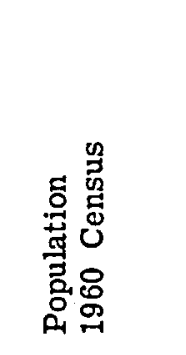 & 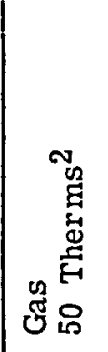 & 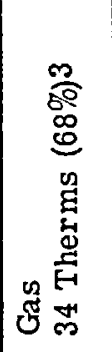 & 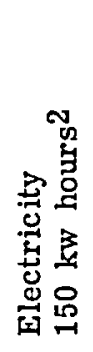 & 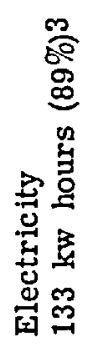 & 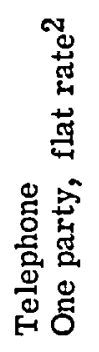 & 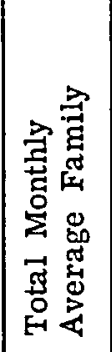 & 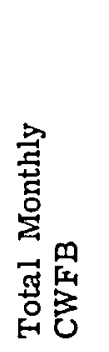 & 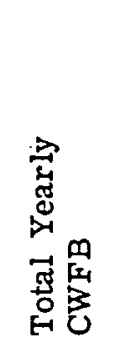 \\
\hline Los Angeles & $2,479,015$ & 5.39 & 3.67 & 4.24 & 3.77 & 4.55 & 14.18 & 11.99 & 143.88 \\
\hline Atlanta & 487,455 & 5.51 & 3.75 & 4.60 & 4.09 & 6.00 & 16.11 & 13.84 & 166.08 \\
\hline Detroit & $1,670,144$ & 5.97 & 4.06 & 5.07 & 4.51 & 6.50 & 17.54 & 15.07 & 180.84 \\
\hline Chicago & $3,550,404$ & 6.98 & 4.75 & 5.33 & 4.74 & 5.60 & 17.91 & 15.09 & 181.08 \\
\hline Washington & 763,956 & 8.21 & 5.58 & 4.30 & 3.83 & 5.75 & 18.26 & 15.16 & 181.92 \\
\hline New York & $7,781,984$ & 10.57 & 7.19 & 6.35 & 5.65 & 5.60 & 22.52 & 18.44 & 221.28 \\
\hline Boston & 697,197 & 12.19 & 8.29 & 6.85 & 6.10 & 5.90 & 24.94 & 20.29 & 243.48 \\
\hline
\end{tabular}
1965.

${ }^{1}$ Adapted from a study by California Public Utilities Commission, Sacramento, January 2 City-wide average.

3Allowance of City Worker's Family Budget. (See Footnote \#15.) 